\title{
KATEGORIA POST-PRAWDY A TEORIA POLITYKI: KILKA UWAG O PROBLEMATYCZNYM STATUSIE MODNEGO KONCEPTU
}

\author{
POST-TRUTH AND POLITICAL THEORY: \\ SOME REMARKS ON A DOUBTFUL STATUS \\ OF POPULAR CONCEPT
}

Piotr Obacz* $\odot$

\begin{abstract}
ABSTRAKT
Artykuł poświęcony jest kategorii post-prawdy i jej wątpliwemu znaczeniu dla badań politologicznych w ogóle i dla teorii polityki w szczególności. W tekście przedstawiono liczne zastrzeżenia pod adresem koncepcji post-prawdy, przede wszystkim definicyjne i teoretyczne, jak również starano się wykazać, iż koncept post-prawdy opiera się na rozumowaniu potocznym i nie spełnia kryteriów naukowości, co wyklucza post-prawdę z katalogu kategorii naukowych. Rozważania osadzono w szerszym kontekście teoriopolitycznym i właśnie na potrzeby teorii polityki wyprowadzono odpowiednie wnioski.
\end{abstract}

Słowa kluczowe: post-prawda; teoria polityki; politologia
This article focuses on the category of post-truth and its doubtful significance for political research in general and particularly for political theory. In the paper, numerous definitional and theoretical objections toward the concept of post-truth were presented, as well as it was attempted to point out that it is based on colloquial reasoning and does not fulfil scientific criteria, which disqualify posttruth from the catalogue of scientific categories. These considerations were embedded in wide theoretical context and congruent conclusions were formulated for enhancement of polish political theory.

Keywords: political science; political theory; post-truth

* Uniwersytet Jagielloński w Krakowie, Wydział Studiów Międzynarodowych i Politycznych. 


\section{WSTĘP}

Pojęcie post-prawda robi zawrotną karierę. Choć kontrowersyjne, jest powszechnie stosowane w dyskursie publicznym ${ }^{1}$ - stąd wyróżnienie przyznane przez Oxford Dictionaries, czemu towarzyszy przekonanie, iż post-prawda może być traktowana jako kategoria deskryptywna i eksplanacyjna.

Badacz rzeczywistości politycznej - ogółu działań jednostek i grup związanych z dążeniem do zdobycia władzy i sprawowaniem jej oraz wpływaniem na decyzje władcze (Koziełło, Maj, Pięta-Szawara, 2014, s. 29; zob. także: Karwat, Ziółkowski, 2013, s. 244-245; Krauz-Mozer, 2007, s. 13-14) - potrzebuje klarownych terminów, precyzyjnych narzędzi i solidnych teoretycznych punktów odniesienia. Jak dotąd „post-prawda” nie wykroczyła poza potoczne i doraźne próby opisu politycznego wymiaru zjawisk społecznych. Jako wątpliwe jawią się przy tym opisowe i tym bardziej wyjaśniające zdolność przedmiotowej kategorii. Wysoce problematyczny wydaje się jej aspekt empiryczny. Post-prawda, wbrew opiniom zwolenników tego pojęcia, stwarza więcej problemów, niż dostarcza pomocy przy naukowej charakterystyce i wyjaśnianiu zjawisk politycznych.

Powyższe skłania do oceny, iż kategorię post-prawdy trudno uznać za użyteczną dla analizy politologicznej i dla teorii polityki. Niniejszy artykuł poświęcony jest temu, jak modny pozanaukowy termin może oddziaływać na proces budowy teorii politycznej, która co do zasady dotyczy istotowych cech fenomenów życia politycznego, jako że badania prowadzone w ramach teorii polityki skupiają się na „dążeniu do wyodrębnienia lub systematyzacji ogólnych właściwości rządzących danym rodzajem zjawisk” (Nocoń, Laska, 2005, s. 13). W tekście przedstawiono główne zastrzeżenia wobec kategorii post-prawdy i stosowania jej w szeroko rozumianej refleksji politologicznej. Zasygnalizowano wątpliwości natury definicyjnej i teoretycznej. Uargumentowano krytyczne stanowisko wobec konceptu post-prawdy, zgodnie z którym nie ma on szans

1 „Krytycznej analizie fenomenu postprawdy we współczesnym dyskursie publicznym” poświęcona była interdyscyplinarna konferencja naukowa zorganizowana w dniach 8-9.06.2017 roku przez Akademię Ignatianum w Krakowie: Postprawda $w$ dyskursie publicznym, organizatorzy: Katedra Socjologii Polityki, Instytut Nauk o Polityce AIK. Zob. więcej na stronie internetowej Akademii Ignatianum w Krakowie: http://www.ignatianum.edu.pl/nauka/konferencje/postprawda-w-dyskursie-publicznym, dostęp: 25.07.2018.

Pokłosiem tamtego wydarzenia są dwie ważne, bo przyczyniające się do wypełnienia luki w polskim piśmiennictwie, obszerne monografie naukowe: Grabowski, Lakomy, Oświecimski (2018); Grabowski, Lakomy, Oświecimski, Pohl (2018). 
trafić nawet do katalogu politologicznych terminów trwale spornych, przede wszystkim ze względu na to, że nie spełnia podstawowych kryteriów naukowości. Rozważania osadzono w szerszym kontekście teoriopolitycznym i właśnie na potrzeby teorii polityki wyprowadzono odpowiednie wnioski. Do zaprezentowanych w artykule ustaleń i ocen autor doszedł poprzez: krytyczne odniesienie się do funkcjonowania przedmiotowej kategorii w dyskursie politycznym i zarazem przenoszenia jej na grunt refleksji naukowej, analizę wpływu stosowania kategorii post-prawdy na kształt teorii politycznej, analizę możliwości teoriopolitycznego uchwycenia istoty post-prawdy.

\section{POST-PRAWDA W DYSKURSIE POLITYCZNYM}

Pod koniec 2016 roku Oxford Dictionaries przyznało słowu post-prawda (post-truth) tytuł Word of the Year². W uzasadnieniu wydawnictwo zwróciło uwage na gwałtowny wzrost częstotliwości stosowania tego słowa we wspomnianym okresie, zaś używane było ono przede wszystkim w dyskursie politycznym różnorakich wypowiedziach publicznych, dotyczących zjawisk społeczno-politycznych, czemu towarzyszyły tezy o tym, że żyjemy w „epoce post-prawdy” (post-truth era), charakteryzującej się m.in. szczególnym sposobem uprawiania polityki (post-truth politics). Decyzja Oxford Dictionaries była wydarzeniem, pisały o niej najważniejsze tytuły prasowe i serwisy internetowe w Polsce i na świecie. Dla wielu autorów „sukces” terminu post-prawda był, jak się wydaje, swoistym dowodem potwierdzającym ich diagnozę społeczno-polityczną (zob. d'Ancona, 2018, s. 13). Oksfordzka instytucja, definiując post-truth jako „przymiotnik odnoszący się do lub opisujący sytuację, w której obiektywne fakty mają mniejsze znaczenie w kształtowaniu opinii publicznej niż odwołania do emocji i osobistych przekonań”, wyraźnie zaznaczyła, że termin post-prawda często jest używany bez dodatkowych objaśnień i uściślania. Jest to widoczne w dyskursie, a w jego ramach w licznych, niestety nierzadko dość mętnych i pochopnych, jeśli idzie o wnioski, analizach i interpretacjach zjawisk społeczno-politycznych, formułowanych w odwołaniu do kategorii post-prawdy.

2 Oxford Dictionaries, Word of the Year 2016 is..., https://en.oxforddictionaries.com/word-of-the-year/word-of-the-year-2016. 
Wielu autorów przekonuje, iż swoisty triumf post-prawdy jest oznaką (dowodem?) „kryzysu rzeczywistości”, objawiającego się tym, że dla coraz większej grupy ludzi „fakty alternatywne są faktami autentycznymi” (Bendyk, 2017, s. 3). Ów „triumf emocjonalnego nad tym, co racjonalne” (d'Ancona, 2018, s. 26; zob. s. 30-41) powoduje, że „coraz mniejsze znaczenie mają fakty, jesteśmy gotowi popierać liderów zdolnych przekonać, że doprowadzą do zmiany, nawet jeśli rozmijają się z prawdą” (Bendyk, 2017a, s. 9); liczy się przede wszystkim „prawda emocji” (Bendyk, 2017a, s. 9). Tłumaczy się, iż „post-prawda nie zaistniała wyłącznie jako retoryka polityków. Powstała w wyniku swoistej współpracy między społecznymi masami, mediami i elitami. A powszechność zjawiska wytworzyła nową jakość” (Czapliński, 2017, s. 13)4. Czym miałaby być ta nowa jakość? Jeśli „strategią nadającą prawdzie drugorzędne znaczenie” (Czapliński, 2017, s. 13), kłamstwem, brakiem uczciwości, oszustwem, formą manipulacji (Keyes, 2017, s. 3-331) lub też przyznawaniem szczególnego znaczenia temu, co subiektywne, to przecież trudno uznać takie postępowanie polityczne czy szerzej - zachowania społeczne za coś, czego wcześniej nie było i co nie byłoby opisane językiem nauki. W próbach objaśnienia istoty post-prawdy - czasem uznawanej za coś oczywistego (Suiter, 2016, s. 25) - opis miesza się z interpretacjami i opiniami. „Post-prawda jest wynikiem kryzysowej dynamiki kapitalizmu, kryzysu demokracji, pandemii nieufności i kultury pogłębiającej społeczne poróżnienia. Post-prawda to nie osobne zjawisko, lecz symptom rozległej katastrofy" (Czapliński, 2017, s. 13). Opierając się na tak niejednoznacznych charakterystykach, ale traktując post-prawdę poważnie, wyprowadza się daleko idące wnioski względem przyszłości demokracji, polityki, partii politycznych5 ${ }^{5}$

3 Jeden z ważniejszych promotorów koncepcji „post-prawdy”, Matthew d'Ancona, słusznie przy tym ocenia, iż „gadanina o kryzysie” jest nieco na wyrost, a nade wszystko bywa po prostu nieznośna (d'Ancona, 2018, s. 9).

4 Łukasz Pawłowski w przedmowie do polskiego wydania książki Ralpha Keyesa Czas postprawdy przypomina, iż praca tego ostatniego ukazała się w 2004 roku - można zatem stwierdzić, iż określenie "nowa jakość” nie do końca koresponduje z dostępnymi ustaleniami i opiniami z początku XXI wieku.

5 Zob. np.: I. Husain, Post-truth politics, Dawn, 13.08.2016, http://epaper.dawn.com/DetailImage. php?StoryImage=13_08_2016_009_002; P. Sinclair, Post-truth politics? Voters don't want visionaries, they want illusionists, Scottish Daily Mail, 23.01.2017, https://www.pressreader.com/uk/scottish-daily-mail/20170123/281840053377829; A. Callcut, The truth about 'post-truth politics', Newsweek, 21.11.2016, http://www.newsweek.com/truth-post-truth-politics-donald-trump-liberals-tonyblair-523198; G. Tsipursky, Towards a post-lies future: fighting "alternative facts" and "post-truth" politics, The Humanist, 21.02.2017, https:/thehumanist.com/magazine/march-april-2017/features/ towards-post-lies-future; R. Kreitner, Post-Truth and Its Consequences: What a 25-Year-Old Essay 
Dysonans, jaki może się tu pojawić, byłby z pewnością mniejszy, gdyby ustalono, czym faktycznie jest post-prawda i na czym polega, czy jest ona zjawiskiem społecznym czy tylko formą zachowania i strategią działania polityków, czy jest charakterystyczna dla podmiotów politycznych, czy też dla różnych innych podmiotów społecznych itd. Czyżby post-prawdę - czymkolwiek przyjmuje się, że jest - tak dalece cechowała nieoznaczoność, iżby nie dało się trwale zidentyfikować jej przejawów i natury?

Anthony Giddens wyraził następującą opinię, zwracając uwagę, iż odkrycie tego, że żyjemy w „post-prawdziwej” rzeczywistości, byłoby doświadczeniem paradoksalnym: „Pojęcie postprawdy wzięło się nie wiadomo skąd i od razu skolonizowało znaczną część publicznego dyskursu. Ja jednak mam do niego stosunek ostrożny Przede wszystkim - gdybyśmy żyli w świecie postprawdy, nie znalibyśmy przecież nawet takiego pojęcia. Ono samo zakłada istnienie jakiejś prawdy, którą od nieprawdy można odróżnić. Nie mówimy więc w gruncie rzeczy o świecie, w którym zanikła kategoria prawdy, tylko o świecie przenikniętym podziałami spowodowanymi przez cyfrową rewolucję.

Samo pojęcie postprawdy można natomiast, moim zdaniem, rozumieć dwojako. Po pierwsze jako nowomowę czy dwumowę (...). Natomiast drugim - i chyba znacznie ciekawszym - ujęciem postprawdy jest doświadczenie funkcjonowania w świecie fragmentarycznym, pokawałkowanym, regulowanym i określanym przez medialne przekazy. W coraz większym stopniu dzisiejsze media konstruują bowiem rzeczywistość, którą rzekomo mają tylko odzwierciedlać.

(...) W zglobalizowanej sieci informacyjnej wiele różnych ośrodków rozpowszechnia rozmaite wizje rzeczywistości i nie istnieje żadna instancja, która je weryfikuje. Nie widzę łatwego wyjścia z tej sytuacji.

Tells Us About the Current Moment, The Nation, 30.11.2016, https://www.thenation.com/article/ post-truth-and-its-consequences-what-a-25-year-old-essay-tells-us-about-the-current-moment/, (tekst poświęcony głośnemu artykułowi Stevena Tesicha z początku lat dziewięćdziesiątych). Zob. także następującą dyskusję: Speed, E., Mannion, R. (2017). The Rise of Post-truth Populism in Pluralist Liberal Democracies: Challenges for Health Policy. International Journal of Health Policy and Management, 6(5), 249-251; McKee, M., Stuckler, D. (2017). “Enemies of the People?" Public Health in the Era of Populist Politics. Comment on "The Rise of Post-truth Populism in Pluralist Liberal Democracies: Challenges for Health Policy”. International Journal of Health Policy and Management, 6(11), 669-672; Powell, M. (2017). This is My (Post) Truth, Tell Me Yours. Comment on "The Rise of Post-truth Populism in Pluralist Liberal Democracies: Challenges for Health Policy”. International Journal of Health Policy and Management, 6(12), 723-725. 
(...) Nie jesteśmy w stanie spędzić całego życia na sprawdzaniu docierających do nas informacji, opieramy się więc na źródłach, którym ufamy - one zaś reprodukują pewien określony obraz rzeczywistości. Nie wiadomo też, jakimi posłużyć się kryteriami, żeby odpowiednio ulokować swoje zaufanie”.

Termin post-prawda okazał się chwytliwym i poręcznym narzędziem dyskursywnym, stosowanym tak w debacie publicznej, jak i w rywalizacji politycznej. Na podstawie pobieżnego przeglądu dostępnych materiałów medialnych (szczegółowa analiza treści nie jest celem artykułu) można odnieść wrażenie, iż liczni autorzy, uznając kategorię postprawdy za właściwie opisującą rzeczywistości, niejako próbowali znaleźć uzasadnienie swych ocen. Można stwierdzić, iż autorzy ci zobaczyli to, co chcieli zobaczyć. Post-prawda to przykład „wygodnej teorii” tłumaczącej wszystko, a przy tym niebezpiecznie bliskiej różnym potocznym wyobrażeniom dotyczącym zjawisk społecznych.

\section{POST-PRAWDA W ŚWIETLE TEORII POLITYKI: CZY JEST MOŻLIWA „TEORIA POST-PRAWDY"?}

Czy post-prawda jest odkrytą własnością rzeczywistości społeczno-politycznej lub cechą jakiegoś jej wycinka czy aspektu? Czy można ją traktować jak prawo społeczne? Czy możliwe jest sformułowanie autonomicznej „teorii post-prawdy”, charakteryzującej jakieś procesy i zjawiska oraz pozwalającej formułować predykcje? To pytania o zasadniczym znaczeniu, niemniej nie pojawiają się one w dyskursie politycznym, choć przecież próby ich rozstrzygnięcia przynajmniej uwiarygodniłyby argumenty zwolenników pojęcia post-prawdy. Istotnie jednak przedstawiciele nauki stawiają pytanie o to, co może ona zrobić z przedmiotową kontrowersyjną kategorią (Butler-Adam, 2017, s. 1), jak należałoby ją pojmować (Radzik, 2018, s. 41-66; Kucharski, 2018, s. 99-114; Gruszczyk, 2018, s. 45-48; Pękala, 2018, s. 106-110; Jarczewski, 2017, s. 5; Laybats, Tredennick, 2016, s. 204) i jakie są źródła post-prawdy (d'Ancona, 2018, s. 13-41, 44-68; Mikołajczyk, 2018, s. 81-98; Nieć, 2018, s. 167-184; Pękala, 2018, s. 100-105). Jak wspomniano wcześniej, nie denotuje ona żadnego nowego zjawiska nawet, lub zwłaszcza jeśli przyjąć, że miałaby dotyczyć sytuacji społecznej, gdy nieprawda, kłamstwo lub manipulacje są powszechnie odbierane jako prawda

6 Ucieka nam świat, wywiad Tomasza Stawiszyńskiego z Anthonym Giddensem. (2017). Przekrój, 2,17 . 
(Butler-Adam, 2017, s. 1), a jednym z mechanizmów utrwalających taki stan są pewne strategie socjotechniczne (Sismondo, 2017, s. 3-47).: "pudrowanie « kłamstwa, które prezentowane jest opinii publicznej jako "prawda «" (Lakomy, Oświecimski, 2018, s. 9) oraz zarzucenie lub celowe zniekształcenie racjonalnego dyskursu politycznego przez jego uczestników, zwłaszcza podmioty polityczne (Laybats, Tredinnick, 2016, s. 204; Fish, 2016, s. 211-212) ${ }^{8}$. Należy przy tym zwrócić uwagę, że obecnie na podstawie dostępnych różnorodnych objaśnień nie sposób precyzyjnie określić, czy kategoria post-prawdy odnosi się do jakiegoś wymiaru komunikacyjnego lub zachowań politycznych; czy jest strategią walki o władzę, jakąś ogólną tendencją (por. d'Ancona, 2018, s. 15) lub nieznaną wcześniej formą ludzkiej - politycznej - aktywności. Nie bardzo wiadomo też, do jakiego stopnia porusza ona problem swoistej „rywalizacji epistemologicznej” w przestrzeni społeczno-politycznej (por. d'Ancona, 2018, s. 8, 19; Jasanoff, Simmet, 2017, s. 764-766), która to rywalizacja „polega tak na wyborze, które prawdy mogą być postrzegane jako naczelne i ważne, jak i na decyzji, które twierdzenia uznać można za prawdziwe i fałszywe" (Sismondo, 2017, s. 4). Jak argumentuje Sergio Sismondo, trudno przyjąć, że „era post-prawdy zaczyna się od wysadzenia w powietrze obecnych struktur wiedzy”, albowiem te ostatnie oparte są na rozbudowanej „infrastrukturze, próbach, pomysłowości i mechanizmach weryfikacji” (Sismondo, 2017, s. 3).

Politologia jako dyscyplina naukowa „oferuje uporządkowaną wiedzę opartą na systematycznych badaniach” i „wytwarza systematyczną wiedzę o tym, co polityczne" (Marsh, Stoker, 2006, s. 10). Teoria politologiczna jako teoria naukowa - „spójny, uporządkowany oraz uzasadniony według wcześniej ustalonych kryteriów system twierdzeń o rzeczywistości” (Pierzchalski, 2017, s. 1; zob. także: Krauz-Mozer, 2017, s. 1; Krauz-Mozer, 2007, s. 62; Koziełło i in., 2014, s. 25-33; Karwat, 2011, s. 75-93) - prezentować ma „porcje” uprawdopodobnionej i usystematyzowanej wiedzy w określonym zakresie. Trudno przyznać, by koncepcja post-prawdy była sformułowana w odwołaniu do tej wiedzy,

7 Tekst ten powstał jako reakcja na artykuł: Fuller, S. (2016). Embrace the inner fox: Post-truth as the STS symmetry principle universalized. Social Epistemology Review and Reply Collective, 25.12.2016, https://social-epistemology.com/2016/12/25/embrace-the-inner-fox-post-truth-as-thests-symmetry-principle-universalized-steve-fuller/. Artykułem polemicznym wobec tego autorstwa S. Sismondo jest m.in. tekst: Collins, H.M., Evans, R.J., Weinel M. (2017). STS as a science or politics? Social Studies of Science, 47(4), 580-586.

8 Zob. również wywiad Rafała Cieńka z Małgorzatą Lisowską-Magdziarz: Postprawda. Niebezpieczne zjawisko. Onet.pl, http://wiadomosci.onet.pl/tylko-w-onecie/postprawda -niebezpieczne-zjawisko/71h1bq5. 
przy użyciu środków, jakie do niej prowadzą. Stąd post-prawda przedstawia się jako niewidoczna dla teorii polityki kategoria badawcza - nieprecyzyjna, mętna, zaś w razie, gdyby miałaby to być propozycja teoretyczna - wątpliwa pod względem wypełniania podstawowych funkcji i zasad formalnych teorii naukowej. Ocena ta podyktowana jest, oprócz zasygnalizowanych wyżej uwag krytycznych, niespełnianiem oczekiwań wynikających z przyjętych kryteriów naukowości, wyznaczonych z kolei na podstawie „poglądów [społeczności naukowej - P.O.] co do sposobów osiągania wiedzy naukowej, a przede wszystkim dotyczących kryteriów pozwalających uznać ją za naukową" (Krauz-Mozer, 2007, s. 40). Koncepcja teoretyczna winna mianowicie wychodzić naprzeciw wymogom: abstrakcyjności (ogólności), precyzyjnego języka i kryteriów opisu zjawisk oraz empirycznej weryfikowalności twierdzeń (Krauz-Mozer, 2007, s. 66-69, zob. także: Koziełło i in., 2014, s. 25-33; Nowak, 2010, s. 62-447; Blok, 2013, s. 278-279). Uwzględniając rozliczne wyobrażenia na temat post-prawdy, nie sposób przyznać tej kategorii ani statusu narzędzia opisowego, ani analitycznego, nie wspominając o kwestii empirycznej weryfikacji hipotezy o post-prawdzie.

Możliwych do wskazania, a podnoszonych w literaturze kontrowersji jest więcej. Dotyczą one głównie, choć nie wyłącznie, rzekomo „post-prawdziwych” zdarzeń i procesów społeczno-politycznych. Wymienia się tutaj, nierzadko w „tonie katastroficznym” (Rose, 2017, s. 558) m.in.: Brexit, zwycięstwo wyborcze Donalda Trumpa i wzrost znaczenia politycznego partii populistycznych w wielu państwach Europy (por. d'Ancona, 2018, s. 13-41; Gruszczyk, 2018, s. 56-58; Zyzik, 2018, s. 85-87). Czy jednak wszystkie te fakty łączy post-prawda? Trudno przyznać przecież, że jest to uniwersalne wyjaśnienie złożonych procesów społecznych w różnych państwach i kulturach politycznych. Jak twierdzą Sheila Jasanoff i Hilton R. Simmet, koncepcja post-prawdy jest „wadliwa, bowiem jest ahistoryczna oraz ignoruje zbiorowe współtworzenie wiedzy i norm w ramach kontekstu politycznego" (Jasanoff, Simmet, 2017, s. 751). Przytoczona opinia przypomina o społecznym tworzeniu znaczenia i korespondujących $\mathrm{z}$ tym procesem zmian w zachowaniach politycznych (Jasanoff, Simmet, 2017, s. 754). Ujmując powyższe jeszcze inaczej, jak z kolei zwraca uwagę Balázs Böcskei, koncept post-prawdy zdaje się zupełnie pomijać to, że rzeczywistość polityczna to przestrzeń dynamiczna, niestała, w której zachodzą ciągłe zmiany i gdzie „dochodzi do konfrontacji różnych koncepcji prawdy” (Böcskei, 2017, s. 258); to w końcu sfera relacji - kontaktu, w ramach którego dochodzi do definiowania faktów (Böcskei, 2017, s. 258-259). Można nad tym ubolewać, choć rolą nauki 
jest wszakże raczej umiejętne rozpoznawanie tych procesów i ich społecznych rezultatów.

Politologiczna „teoria post-prawdy” wydaje się przeto czymś chimerycznym. Pod względem przedmiotowym musiałaby dopuszczać znaczącą - zbyt dużą jak na teorię - możliwość zmieniania pojmowania jej głównego obiektu, by badania były możliwe. Co więcej, trudno sobie wyobrazić taką teorię, która rozpoznawałaby i obejmowała swym zakresem wielość, być może niezliczonych czynników i zależności między nimi, tworzących określone zjawisko. Jeśli chodzi o założenia ontologiczne, „teoria post-prawdy” $\mathrm{z}$ trudem mogłaby przesądzić zagadnienie istnienia niezależnego obserwatora oraz „podmiotu rozstrzygającego” o prawdzie i fałszu, a także - co ważniejsze - zagadnienie samej prawdy i wielości prawd. „Teoria post-prawdy” skazana byłaby tu na wahanie się między solipsyzmem i relatywizmem a epistemologicznym absolutyzmem. Zasadne wydaje się spostrzeżenie Lecha Rubisza, iż współczesne nauki społeczne, inaczej niż myślenie potoczne, z trudem, ale jednak dopuszczają możliwość istnienia stanu, „w którym nie istnieje jedna prawda albo też nie da się jej obiektywnie ustalić” (Rubisz, 2013, s. 168) w związku z charakterem naszych praktyk społecznych i relacyjnych uwikłań. Kolejną kwestią jest to, iż twierdzenia dotyczące post-prawdy, a zwłaszcza jej rzekomej powszechności i skali wpływu na funkcjonowanie systemów politycznych, nie wydają się sądami empirycznymi, a w związku z tym „teoria post-prawdy" w aspekcie metodologicznym musiałaby przyjąć jako konieczny wymóg falsyfikowalności i empirycznej weryfikacji (Rehfeld, 2010, s. 4729). Wydaje się, że pewnym ratunkiem dla „teorii post-prawdy” mogłoby być wyrażenie jej w języku teorii interpretacjonistycznej, tj. skupiającej się na „znaczeniach, które określają kształt działań i instytucji oraz na sposobach kształtowania tych działań i instytucji” (Bevir, Rhodes, 2006, s. 131), a także „orzekającej o znaczeniu wydarzeń politycznych dla ich uczestników i/oraz oferującej badaczowi interpretację tych wydarzeń" (Rehfeld, 2010, s .475). Niemniej jednak rygor naukowości musiałby być przestrzegany. Jak wyjaśnia Eugeniusz Ponczek: „Za teorię polityki można uznać hipotetyczny układ w miarę koherentnych uogólnień zakładających mniej lub bardziej prawdopodobną sprawdzalność odkrytych prawidłowości odnoszących się do realiów politycznych” (Ponczek, 2017, s. 53). „Za konstatacje spełniające kryterium naukowości w sferze dociekań politologicznych, które byłyby zintegrowane w konceptualnej strukturze takiej czy innej teorii polityki,

9 Polemikę z tezami Autora dotyczącymi „ofensywnej teorii polityki” (zob. s. 465-471, 478-479) podjął m.in. R.J. Corbett (2011). 
można by uznać hipotetyczny układ koherentnych uogólnień podlegających sprawdzalności w obecnych realiach politycznych. Tego rodzaju rozpoznanie prawidłowości o atrybutach prawdopodobieństwa, jeśli chodzi o osobliwości i zmienności „świata polityki”, cechowałoby dążenie do uzyskania optymalnej sprawczości w sferze stosunków politycznych i procesów politycznych z uwzględnieniem uwarunkowań sytuacyjnych" (Ponczek, 2017, s. 53).

Kategoria post-prawdy,, przynajmniej w takim kształcie, w jakim jest obecnie prezentowana w dyskursie, nie prowadzi do sformułowania rzetelnej formuły teoriopolitycznej (zob. Chodubski, 2013, s. 443-444), albowiem nie odstaje od „myślenia uwikłanego w potoczne oczywistości, spekulatywne koncepcje i domysły rodem z »Archiwum X«" (Krauz-Mozer, 2017, s. 15) ${ }^{10}$.

\section{TEORIA POLITYKI W ŚWIETLE „POST-PRAWDY”: WPŁYW ROZUMOWANIA POTOCZNEGO NA KSZTAŁT TEORII}

"Wszelkie systematyczne rozumienie rzeczywistości politycznej wymaga teorii” (Dunn, 2015, s. 494). Dodatkowo oczekuje się, że teoretyk polityki „oprze się pewnym formom zwichniętej retoryki” (Gunnell, 2010, s. 674), która mogłaby utrudnić wypełnienie celów naukowych, takich jak opis i wyjaśnienie zjawisk. Wydaje się, iż przywiązanie do kategorii post-prawdy w analizie politologicznej mogłoby nadmiernie zmienić jej charakter: $\mathrm{z}$ badania opartego na ścisłych kryteriach na „publicystyczną ekspresję własnej opinii” (Corbett, 2011, s. 570). „Nie istnieje taki dyskurs politologiczny, którego znaczenie byłoby wyłącznie poznawcze, gdyż zawsze jest on wpisany w określoną rzeczywistość społeczną i uwikłany w teraźniejszy kontekst zdarzeń, zróżnicowanych interesów, potrzeb, wartości, nadających określony sens różnym aspektom ludzkiego funkcjonowania" (Krauz-Mozer, 2009, s. 11).

Przytoczone słowa przypominają, że zawsze istnieje pokusa, by interesujący badacza aspekt rzeczywistości społecznej opisać językiem jak najbardziej teraźniejszym, tj. odpowiadającym aktualnym zwyczajom, nastrojom i tendencjom, by uchwycić je pełniej. $Z$ drugiej strony istnieje realne zagrożenie - do którego zbliża kategoria post-prawdy - „dominacji potocznego doświadczenia społeczno-poli-

10 Wydaje się, że w najlepszym razie może to być metaforyczny opis pewnych wyobrażeń czy intuicji, w najgorszym zaś po prostu forma szukania potwierdzeń pewnego poglądu. 
tycznego" (Chodubski, 2009, s. 35'11) nad naukowym punktem widzenia. Takie terminy, jak np. „rozłam”, „rewolucja”, ,autorytaryzm” czy „pluralizm”, odnoszą się do konkretnych zjawisk, sytuacji i systemów. Z kolei takie kontrowersyjne, odwołujące się do zasadniczych aktywności politycznych, ideałów i wartości terminy, jak np. „polityka”, ,wolność”, ,,sprawiedliwość”, ,władza” (Heywood, 2008, s. 6-7) są najważniejszymi, które organizują refleksję społeczno-polityczną, działalność badawczą i dyskusję badaczy, w toku której ustalone zostaje naukowe rozumienie tych terminów. Post-prawda jawi się na tym tle jako powierzchowny i pochopny opis rzeczywistości. Posługując się wywodem Andrzeja Chodubskiego, stwierdzić można, iż przedmiotowa kategoria „odbija potoczną recepcję rzeczywistości, a też nie jest wolny od ładunku emocjonalnego, co wyraża się w pozytywnym bądź negatywnym stosunku badacza do rozpoznawanych zjawisk i procesów" (Chodubski, 2009, s. 49).

Jeśli wierzyć w koncepcję post-prawdy, trzeba by ponownie rozważyć i zredefiniować rolę polityka, znaczenie prawdy, źródła i sens różnych wyborów i decyzji politycznych. Niemniej jednak, podczas gdy post-prawda w zasadzie w ogóle nie pomaga w powiększeniu wiedzy o opinii publicznej, państwie, wyróżnikach, mechanizmach i naturze politycznego wymiaru rzeczywistości społecznej (por. Klementewicz, 2013, s. 31-35; Karwat, 2011, s. 3-6 wersji elektronicznej) oraz „odtworzeniu realnych działań politycznych podmiotów polityki” (Sielski, 2009, s. 77), byłoby to próżne zajęcie. Niewątpliwie jednak post-prawda i kontrowersje wokół tej kategorii przypominają o tym, co politologom jest wiadome i co stanowi rdzeń pewnych stanowisk metodologicznych: „w polityce ważniejsze są skutki subiektywne (wyobrażeniowe), a nie obiektywne, dlatego przede wszystkim nakazem politologii jest badać te skutki” (Sielski, 2009, s. 76) oraz: „w polityce przeważają interesy aksjologiczno-polityczne, dlatego nakazem politologii jest badać przede wszystkim tego typu interesy" (Sielski, 2009, s. 75) ${ }^{12}$. Wątpliwe jest jednak, by post-prawda miała przyczynić się do wzmocnienia świadomości metodologicznej i teoretycznej badaczy rzeczywistości społeczno-politycznej i czy w ogóle jest to potrzebne akurat z pomocą post-prawdy.

Rację ma Pertti Alasuutari, pisząc, że „opisy ludzkiej rzeczywistości są jej nieodłączną częścią" (Alasuutari, 2004, s. 163) i mogą mieć znaczny wpływ na

11 Dodać warto w ślad za B. Krauz-Mozer, iż „politologia to coś różnego od wiedzy potocznej: nie jest też ani czystą empirią, ani czystą teorią" (Krauz-Mozer, 2007, s. 9).

12 Zdarzenia tak często wymieniane jako przejawy post-prawdy wydają się właśnie tego rodzaju przykładami, o których pisze Jerzy Sielski. Ujawniają one bowiem „fundamentalną naturę polityki, gdzie nie ma niepodważalnych faktów, istniejących tylko w jeden sposób” (Böcskei, 2017, s. 258). 
jej kształt. W przypadku kategorii post-prawdy, będącej wynikiem myślenia potocznego, spostrzeżenie to jest wyjątkowo trafne. Jak pisał w innym kontekście Ronald David Laing: „Wybór składni i słownika jest aktem politycznym, definiującym i określającym to, w jaki sposób »fakty« mają być doświadczane. W rzeczywistości wybór ów sięga nieco dalej i może nawet tworzyć fakty, które się później bada" (Laing, 2005, s. 64). Jest to oczywista przestroga przed uprawianiem - również przez ludzi nauki - swoistej „polityki prawdy” (por. Alasuutari, 2004, s. 162-168; Baderin, 2016, s. 209-233).

\section{KONKLUZJE}

Termin post-prawda zadomowił się w dyskursie publicznym za sprawą zadziwiającego klimatu, który charakteryzuje się m.in. wieszczeniem „kryzysu rzeczywistości", kryzysu demokracji, erozji zaufania, rozpadu wspólnoty oraz wołaniem o „nową narracje” (zob. np. Bendyk, 2017a, s. 11), która miałaby być obroną przed post-prawdą. Wydaje się, że przynajmniej w pewnej mierze owa potrzeba „nowej narracji” przyczyniła się do rozwoju narracji o post-prawdzie, napędzanego pochopnymi wnioskami z pobieżnych obserwacji i niejednokrotnie dyletanckim podejściem do lokalnych i globalnych procesów społeczno-politycznych. Post-prawda to kategoria moralnego niepokoju, w której odciśnięta jest publicystyczna niecierpliwość.

Nierzadko badacze i komentatorzy życia społeczno-politycznego poddają się entuzjazmowi związanemu z atrakcyjnością lub iluzyjną nowością jakichś terminów czy koncepcji. Wyrażają przy tym zadowolenie z powodu ich rzekomego powabu i niezwykłości, mają wrażenie, że celnie i kompletnie opisują one otaczającą rzeczywistość. Nie inaczej jest z kategorią post-prawdy. Warto jednak zwrócić uwagę, że w nauce droga wiedzie od badań, obserwacji i teoretycznych interpretacji do ekscytacji z powodu wyników, jakie się uzyskuje (nieważne już czy dlatego, że zawodzą badacza, czy też dlatego, że zdają się potwierdzać jakieś przypuszczenia) - drogę odwrotną nauka zasadnie odrzuca. Oznacza to, że ekscytacja z jakiegoś powodu nie może być źródłem twierdzeń naukowych, których cechą jest to, że roszczą sobie prawo do statusu wiarygodnych opisów i wyjaśnień rzeczywistości lub jakiegoś jej wycinku. Modny dziś koncept post-prawdy jest od takiego statusu daleki, także $\mathrm{z}$ tego powodu, iż jego stosowanie $\mathrm{w}$ dyskursie publicznym jak dotąd odbywało się $\mathrm{z}$ pominięciem wszelkich naukowych rygorów. Małgorzata Lisowska-Magdziarz wyraża zasadną opinię, 
iż „postprawda to absurdalne pojęcie”, które zostało „niedbale wprowadzone do sfery komunikacji politycznej, gdzie okazało się propagandowo skuteczne"13 (zob. także: Płoszczyniec, 2018, s. 141-166). Taka kategoria nie jest teoretykom polityki i pozostałym grupom politologów do niczego potrzebna. Jednocześnie warto nadmienić, iż składniki tego, co różni autorzy określają jako elementy definicyjne post-prawdy, mogą - istotnie - wskazywać obszary, kierunki czy przedmiot badań. I tak np. politolodzy skupiający się na komunikacji politycznej mogą weryfikować rozliczne hipotezy dotyczące m.in. sposobu powstawania fake news i ich roli w dyskursie politycznym (zob. np.: Piotrowska, 2018, s. 185-204; por. Rydlewski, 2017, s. 81-89); badacze sięgający po narzędzia psychologiczne mogą rozwijać dociekania nad kwestią emocji w zachowaniach politycznych, w tym w procesach decyzyjnych; teoretycy polityki mają sposobność konfrontacji stosowanych teorii politycznych lub konkretnych kategorii teoriopolitycznych z nowymi próbami opisu rzeczywistości. Nawet filozoficznie zorientowani politolodzy, „unikając pochopnych sądów”, mogą „formułować długofalowe wizje tego, jak zbudować etos i uczciwość w życiu publicznym (Rose, 2017, s. 558). Mimo wszystko jednak post-prawda nie stanowi czynnika, który rewolucjonizuje, czy nawet znacząco modyfikuje perspektywy badawcze w politologii.

Post-prawda powstała jako quasi-naukowy opis rzeczywistości i wydaje się, że takim właśnie pozostanie. Tak chętnie stosowana kategoria post-prawdy jawi się jednak jako przykład naiwnej spekulacji i (zbyt) daleko idącego, mylnego przekonania, że to, co obserwujemy, musi dowodzić tego, co przyjęliśmy wcześniej za właściwy opis zjawisk i procesów społecznych (por. Böcskei, 2017, s. 258-259; Rose, 2017, s. 558; Jasanoff, Simmet, 2017, s. 751-754). Należy przy tym zauważyć, iż opisowe i wyjaśniające roszczenia terminu post-prawda są żywo promowane przez tych uczestników dyskursu politycznego, którzy mają (w pełni zrozumiałą) aspirację kształtowania tego dyskursu i zmiany relacji władzy. Patrząc jednak na kategorię post-prawdy z perspektywy kryteriów naukowości, wydaje się ona czymś tak mętnym, niejasnym i „naciąganym”, że trudno ją uznać użyteczną dla badań politologicznych w ogóle i dla teorii polityki w szczególności.

13 Postprawda. Niebezpieczne zjawisko, wywiad Rafała Cieńka z Małgorzatą Lisowską-Magdziarz. Onet.pl, 15.02. 2017, http://wiadomosci.onet.pl/tylko-w-onecie/postprawda-niebezpieczne-zjawisko /71h1bq5. 
BibliOgRAFIA:

Alasuutari, P. (2004). Social Theory \& Human Reality. London: Sage Publications Ltd.

Baderin, A. (2016). Political Theory and Public Opinion: Against Democratic Restraint. Politics, Philosophy \& Economics, 15(3), 209-233.

Bendyk E. (2017). Jak żyć w epoce post-prawdy? Niezbędnik Inteligenta (Polityka), 1.

Bendyk E. (2017). Prolog: kryzys rzeczywistości. Niezbędnik Inteligenta (Polityka), 1.

Bevir, M., Rhodes, R.A.W. (2006). Teoria interpretacjonistyczna. W: D. Marsh, G. Stoker (red.). Teorie i metody w naukach politycznych (s. 131-152). Kraków: Wydawnictwo Uniwersytetu Jagiellońskiego.

Blok, Z. (2013). Rodzaje teoretycznej wiedzy o polityce a podejścia badawcze. W: B. Krauz-Mozer, P. Ścigaj (red.). Podejścia badawcze i metodologiczne w nauce o polityce (s. 277-289). Kraków: Księgarnia Akademicka.

Böcskei, B. (2017). "Post-Truth Politics" as the Normal State of Politics. Journal for Critical Organization Inquiry, 15(3-4), 257-260.

Butler-Adam, J. (2017). What Could Scientists do About 'Post-Truth'? South African Journal of Science, 113(1/2), 1 .

Chodubski, A. (2013). O kształtowaniu się metody politologicznej. W: B. Krauz-Mozer, P. Ścigaj (red.). Podejścia badawcze i metodologiczne w nauce o polityce (s. 435-445). Kraków: Księgarnia Akademicka.

Chodubski, A. (2009). Powołanie naukowe a potoczność uprawiania politologii. W: A. Antoszewski, A. Dumała, B. Krauz-Mozer, K. Radzik (red.). Teoretyczne i metodologiczne wyzwania badań politologicznych w Polsce (s. 35-49). Lublin: Wydawnictwo Uniwersytetu Marii Curie-Skłodowskiej.

Corbett, R.J. (2011). Political Theory within Political Science. PS: Political Science and Politics, 44(3), 565-570.

Czapliński, P. (2017). Nie cała prawda o post-prawdzie. Niezbędnik Inteligenta (Polityka), 1. d'Ancona, M. (2018). Postprawda. Warszawa: Wydawnictwo Krytyki Politycznej.

Dunn, J. (2015). The Impact of Political Theory. Political Studies Review, 13, 494-499.

Fish, W. (2016). "Post-Truth" Politics and Illusory Democracy. Psychotherapy and Politics International, 14(3), 211-213.

Gruszczyk, A. (2018). Moja prawda jest najmojsza, czyli postprawda w praktyce. W: T. Grabowski, M. Lakomy, K. Oświecimski (red.). Postprawda jako zagrożenie dla dyskursu publicznego (s. 45-64). Kraków: Wydawnictwo Naukowe Akademii Ignatianum w Krakowie.

Gunnell, J.G. (2010). Professing Political Theory. Political Reseach Quarterly, 63(3), 674-679. Heywood, A. (2008). Klucz do politologii. Najważniejsze ideologie, systemy, postaci. Warszawa: Wydawnictwo Naukowe PWN. Jarczewski, A. (2017). Prawda po epoce post-truth. Katowice: „Śląsk” Sp. z o.o. Wydawnictwo Naukowe.

Jasanoff, S., Simmet, H.R. (2017). No Funeral Bells: Public Reason in a 'Post-Truth' Age. Social Studies of Science, 47(5), 751-770.

Karwat, M. (2011). Rodzaje teorii w nauce o polityce. W: Z. Blok (red.). Czym jest teoria w politologii? (s. 75-93). Warszawa: Dom Wydawniczy ELIPSA. 
Karwat, M., Ziółkowski, J. (red.) (2013). Leksykon pojęć politycznych. Warszawa: Dom Wydawniczy ELIPSA. Keyes, R. (2017). Czas postprawdy. Nieszczerość i oszustwa $w$ codziennym życiu. Warszawa: PWN.

Klementewicz, T. (2013). Politolog w labiryncie paradygmatów - pułapki eklektyzmu. W: B. Krauz-Mozer, P. Ścigaj (red.). Podejścia badawcze $i$ metodologiczne w nauce o polityce (s. 31-43). Kraków: Księgarnia Akademicka.

Koziełło, T., Maj, P., Pięta-Szawara, A. (2014). Perspektywy badawcze i dylematy teorii polityki. Rzeszów: Wydawnictwo Uniwersytetu Rzeszowskiego.

Krauz-Mozer B. (2017). Spotkajmy się - wszyscy jesteśmy teoretykami!. Teoria Polityki, 1, $11-24$.

Krauz-Mozer B. (2007). Teorie polityki. Założenia metodologiczne. Warszawa: Wydawnictwo Naukowe PWN.

Krauz-Mozer B. (2009). Politologia z punktu widzenia metodologii sensu largo. W: A. Antoszewski, A. Dumała, B. Krauz-Mozer, K. Radzik (red.). Teoretyczne i metodologiczne wyzwania badań politologicznych w Polsce (s. 11-26). Lublin: Wydawnictwo Uniwersytetu Marii Curie-Skłodowskiej.

Kucharski, J. (2018). Postprawda - próba dookreślenia znaczenia. W: T.W. Grabowski, M. Lakomy, K. Oświecimski, A. Pohl (red.). Postprawda. Spojrzenie krytyczne (s. 99-114). Kraków: Wydawnictwo Naukowe Akademii Ignatianum w Krakowie.

Laing, R.D. (2005). Polityka doświadczenia. Rajski ptak. Warszaw: Wydawnictwo KR.

Lakomy, M., Oświecimski, K. (2018). Postprawda a filozofia, nauki o mediach i nauka społeczna Kościoła katolickiego. Wprowadzenie. W: T.W. Grabowski, M. Lakomy, K. Oświecimski, A. Pohl (red.). Postprawda. Spojrzenie krytyczne (s. 9-23). Kraków: Wydawnictwo Naukowe Akademii Ignatianum w Krakowie.

Laybats, C., Tredinnick, L. (2016). Post Truth, Information, and Emotion. Business Information Review, 33(4), 204-206.

Marsh, D., Stoker, G. (2006). Wprowadzenie. W: D. Marsh, G. Stoker (red.). Teorie i metody w naukach politycznych (s. 1-15). Kraków: Wydawnictwo Uniwersytetu Jagiellońskiego.

McKee, M., Stuckler D. (2017). “Enemies of the People?” Public Health in the Era of Populist Politics. Comment on "The Rise of Post-Truth Populism in Pluralist Liberal Democracies: Challenges for Health Policy”. International Journal of Health Policy and Management, 6(11), 669-672.

Mikołajczyk, H. (2018). Prawda sacrum, prawda profanum, czyli o kulturowej genezie postprawdy. W: T.W. Grabowski, M. Lakomy, K. Oświecimski, A. Pohl (red.). Postprawda. Spojrzenie krytyczne (s. 81-98). Kraków: Wydawnictwo Naukowe Akademii Ignatianum w Krakowie.

Nieć, M. (2018). U źródeł aktora politycznego. Kontekst postprawdy. W: T.W. Grabowski, M. Lakomy, K. Oświecimski, A. Pohl (red.). Postprawda. Spojrzenie krytyczne (s. 167-184). Kraków: Wydawnictwo Naukowe Akademii Ignatianum w Krakowie.

Nocoń, J., Laska, A. (2005). Teoria polityki. Wprowadzenie. Warszawa: Wydawnictwo Wyższej Szkoły Pedagogicznej TWP.

Nowak S. (2010). Metodologia badań społecznych. Warszawa: Wydawnictwo Naukowe PWN. 
Pękala, M. (2018). Racjonalny ustawodawca w czasach postprawdy. W: T. Grabowski, M. Lakomy, K. Oświecimski (red.). Postprawda jako zagrożenie dla dyskursu publicznego (s. 99-124). Kraków: Wydawnictwo Naukowe Akademii Ignatianum w Krakowie. Pierzchalski F. (2017). Wyobraźnia twórcza - o źródłach teoretyzowania w nauce o polityce. Teoria Polityki, 1,25-43.

Piotrowska, M. (2018). Kampania wyborcza w „czasach postprawdy”: fake news w kampanii do Bundestagu w Niemczech w 2017 roku. W: T. Grabowski, M. Lakomy, K. Oświecimski (red.). Postprawda jako zagrożenie dla dyskursu publicznego (s. 185-204). Kraków: Wydawnictwo Naukowe Akademii Ignatianum w Krakowie.

Płoszczyniec, A. (2018). Zbędność i szkodliwość pojęcia postprawdy. W: T.W. Grabowski, M. Lakomy, K. Oświecimski, A. Pohl (red.). Postprawda. Spojrzenie krytyczne (s. 141-166). Kraków: Wydawnictwo Naukowe Akademii Ignatianum w Krakowie.

Ponczek E. (2017). Możliwości i ograniczenia kreowania teorii polityki. Teoria Polityki, 1, $45-62$.

Postprawda. Niebezpieczne zjawisko. Wywiad Rafała Cieńka z Małgorzatą Lisowską-Magdziarz. Onet.pl, 15.02.2017. Pobrane z: http://wiadomosci.onet.pl/tylko-w-onecie/ postprawda-niebezpieczne-zjawisko/71h1bq5.

Powell, M. (2018). This Is My (Post) Truth, Tell Me Yours. Comment on "The Rise of Post-truth Populism in Pluralist Liberal Democracies: Challenges for Health Policy". International Journal of Health Policy and Management, 6(12), 732-725.

Radzik, R. (2018). Postprawda: przyczyny, przejawy i skutki zaistnienia. W: T.W. Grabowski, M. Lakomy, K. Oświecimski, A. Pohl (red.). Postprawda. Spojrzenie krytyczne (s. 41-66). Kraków: Wydawnictwo Naukowe Akademii Ignatianum w Krakowie.

Rehfeld, A. (2010). Offensive Political Theory. Perspectives on Politics, 8(2), 465-486.

Rose, J. (2017). Brexit, Trump, and Post-Truth Politics. Public Integrity, 19, 555-558.

Rubisz, L. (2013). Neutralność jako kryterium naukowości politologii. W: B. Krauz-Mozer, P. Ścigaj (red.). Podejścia badawcze i metodologiczne w nauce o polityce (s. 163-184). Kraków: Księgarnia Akademicka.

Rydlewski, G. (2017). Coś więcej niż spór o jakość rzadzenia. Warszawa: Dom Wydawniczy ELIPSA.

Sielski, J. (2009). Wyznaczniki politologii. W: A. Antoszewski, A. Dumała, B. Krauz-Mozer, K. Radzik (red.). Teoretyczne i metodologiczne wyzwania badań politologicznych w Polsce (75-84). Lublin: Wydawnictwo Uniwersytetu Marii Curie-Skłodowskiej.

Sismondo, S. (2017). Post-Truth? Social Studies of Science, 47(1), 3-6.

Speed, E., Mannion, R. (2017). The Rise of Post-Truth Populism in Pluralist Liberal Democracies: Challenges for Health Policy. International Journal of Health Policy and Management, 6(5), 249-251.

Suiter, J. (2016). Post-Truth Politics. Political Insight, 7(3), 25-27.

Ucieka nam świat, wywiad Tomasza Stawiszyńskiego z Anthonym Giddensem. (2017). Przekrój, 2, 16-19.

Zyzik, R. (2018). Postprawda a kaskada dostępności. Ślepa uliczka dyskursu publicznego. W: T. Grabowski, M. Lakomy, K. Oświecimski (red.). Postprawda jako zagrożenie dla dyskursu publicznego (s. 85-98). Kraków: Wydawnictwo Naukowe Akademii Ignatianum w Krakowie. 